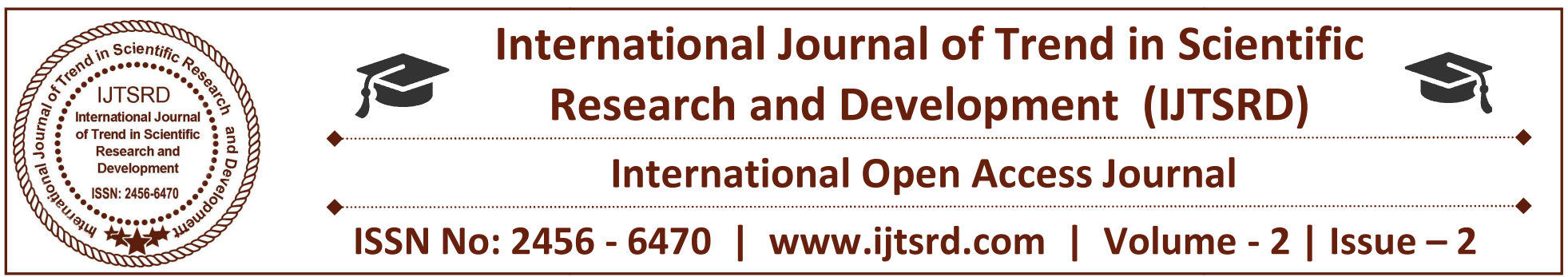

\title{
A Complete Review on Rubia Cordifolia
}

\author{
Dr. Siva Rami Reddy E \\ Research Scholar, Faculty of Homoeopathy, Tantia University, \\ Sri Ganganagar, Rajasthan, India
}

\begin{abstract}
Medicinal herbs are significant source of synthetic and herbal drugs. In the commercial market, medicinal herbs are used as raw drugs, extracts or tinctures. Isolated active constituents are used for applied research. For the last few decades, phytochemistry has been making rapid progress and herbal products are becoming popular. The formulations incorporate single herb or more than two herbs (polyherbal formulations). Medicinal herb contains multitude of chemical compounds like alkaloids, glycosides, saponins, resins, oleoresins, sesquiterpene, lactones and oils. Today there is growing interest in chemical composition of plant based medicines. Several bioactive constituents have been isolated and studied for pharmacological activity. Rubia cordifolia is an important medicinal plant commonly used in the traditional and AYUSH system of medicine for treatment of different ailments. This review illustrates its major constituents, pharmacological actions substantiating the claims made about this plant in the traditional system of medicine and its clinical applications.
\end{abstract}

diarrhorea, scabies, venereal disease, ulcers, snake bite, etc ${ }^{2}$. More than $80 \%$ of the world's population still depends upon traditional medicines for various skin diseases ${ }^{3}$. Herbal medicines in wound management involve disinfection, debridement and providing a moist environment to encourage the establishment of the suitable environment for natural healing process ${ }^{3,4}$.

Rubia cordifolia (Rubiaceae) is also known as, Manjishtha, Indian madder which is distributed throughout India ${ }^{5}$. It is found throughout the hilly districts of India from northwest Himalayas eastwards, ascending to $8000 \mathrm{ft}$ and southwards to Ceylon. The roots of this plant are of high medicinal value and are recognized as official ${ }^{6}$. This perennial herbaceous prickly creeper or climber is upto $10 \mathrm{~m}$ long, found throughout the country ascending to 3750 $\mathrm{m}$ and grow well in light (sandy), medium (loamy) and heavy (clay) soils ${ }^{7}$.

The family Rubiaceae comprises about 450 genera and 6500 species and includes trees, shrubs and

Keywords: Rubia cordifolia, Phytochemical, pharmacological study

infrequently herbs. Rubia cordifolia L. (Rubiaceae), also known as 'manjistha', is a perennial, herbaceous climbing plant, with very long roots, cylindrical, flexuous, with a thin red bark. Stems often have a long, rough, grooved, woody base. Plants belonging to this family are known to contain substantial amounts of anthraquinones, especially in the roots ${ }^{8}$. The traditional therapeutic use of the plant has been for skin disorders and for anticancer activity. Furthermore, the anthraquinones of the Rubiaceae 
International Journal of Trend in Scientific Research and Development (IJTSRD) ISSN: 2456-6470

family exhibit some interesting in vivo biological activities, such as antitumor ${ }^{9}$, anti-inflammatory ${ }^{10}$, hepatoprotective ${ }^{11-13}$, antimicrobial and immunomodulatory.

$\mathrm{R}$ ubia cordifolia (Indian Madder) is growing most often near streams and rivers along the upper Ghats in evergreen forests up to $3750 \mathrm{~m}$ above sea level. It is a perennial, prickly or scabrous, climbing herb belongs to rubiaceae. Leaves variable, arranged four in a whorl, cordateovate to ovate lanceolate, base slightly cordate, 1 petioles are quadrangular, sometimes prickly on the angles, glabrous and shining. Stipules are absent. Stems is slender, rough, four angled with sharp recurved prickles on the ridges, which are often many yards long, becoming slightly woody at the base. Flowers are in cymes, greenish white. Fruits are didymous or globose, smooth, shining and purplish black when ripe. ${ }^{14-18}$

\section{Table 1: Vernacular Names}

\begin{tabular}{|l|l|}
\hline \multicolumn{1}{|c|}{ Places } & \multicolumn{1}{c|}{ Indian languages } \\
\hline Assam & Majathi \\
\hline Bengali & Manjith \\
\hline Bihar & Majith \\
\hline Marathi & Madar \\
\hline Kannada & Siomalate,Siragatti,Manjustha \\
\hline Kashmir & Dandlu \\
\hline Khasi & Ryhoi,Soh-misem \\
\hline
\end{tabular}

\begin{tabular}{|l|l|}
\hline Urdu & Mañjișțha \\
\hline Punjab & $\begin{array}{l}\text { Kukarphali, Tiuru, Manjit, } \\
\text { Sheni, Mitu, Runang }\end{array}$ \\
\hline Tamil & Shevelli,Manjitti \\
\hline Telugu & $\begin{array}{l}\text { Tamravalli, Chiranji, } \\
\text { Manjestatīga }\end{array}$ \\
\hline Malayalam & Poont, Manjetti \\
\hline Nepal & Manjito \\
\hline Oriya & Barheipani, Mañjișțha \\
\hline Khasi & Ryhoi, Soh-misem \\
\hline Urdu & Mañjișțha \\
\hline Naga & Enhu, Chenhu \\
\hline Manipur & Moyam \\
\hline Lepecha & Vhyem \\
\hline
\end{tabular}

It is famous as Varnya in the traditional medicine. At present it is used mainly as natural colouring agent in the fabrics industry. It is often debated which is the useful part of Rubia cordifolia. In the market we come across the samples which appear as stems as well as roots. In Vaidya chintamani, Rubia cordifolia is enumerated among the kandasara dravyas. Therefore, it may be concluded that root is the useful part of Rubia cordifolia. Stem of Rubia cordifolia which are somewhat quadrangular and have a smooth greenish yellow outer surface is generally used as a substitute of its root. Olden landia umbellata or Hispida indica known as chayaver in Tamil is an adulterant of Rubia cordifolia. ${ }^{19,20}$

\section{Figure -1: Different Stages of Rubia cordifolia}

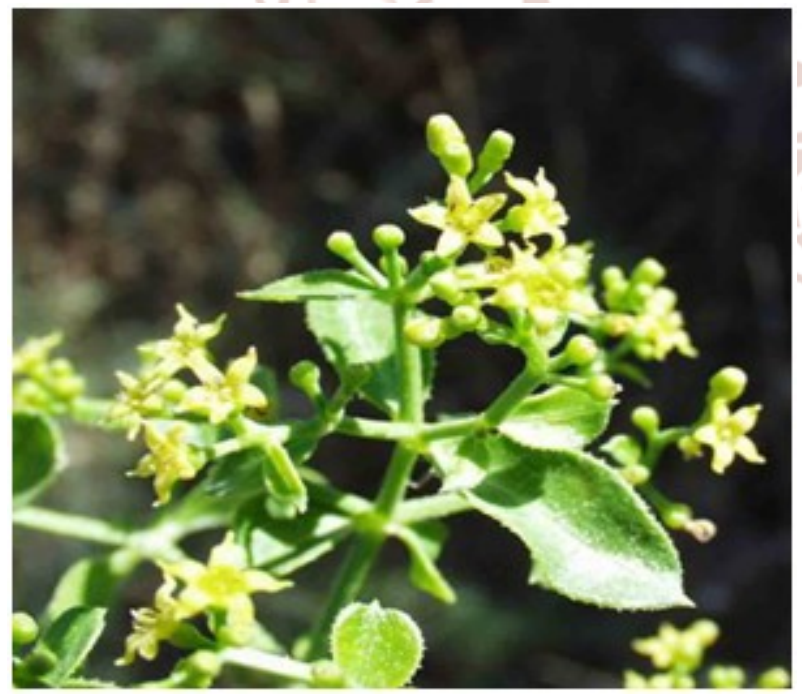

(A) Flower in Stage

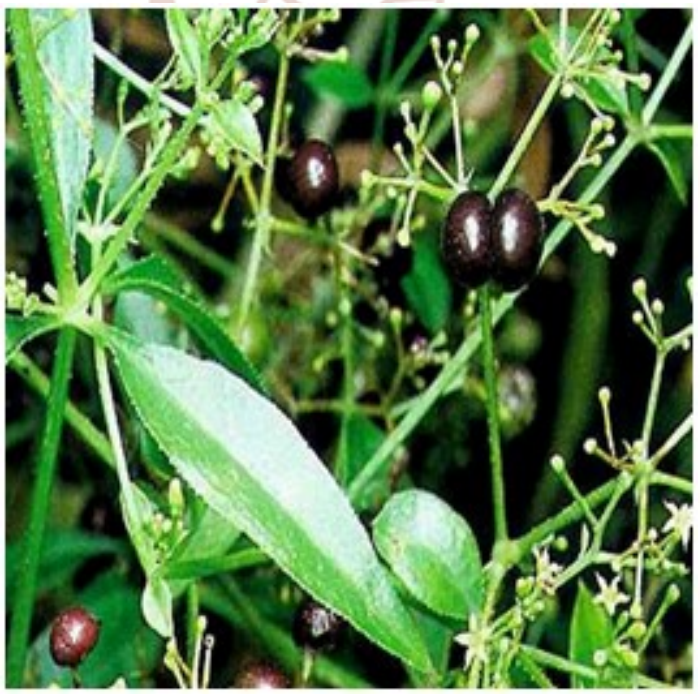

(B) Fruiting Stage 

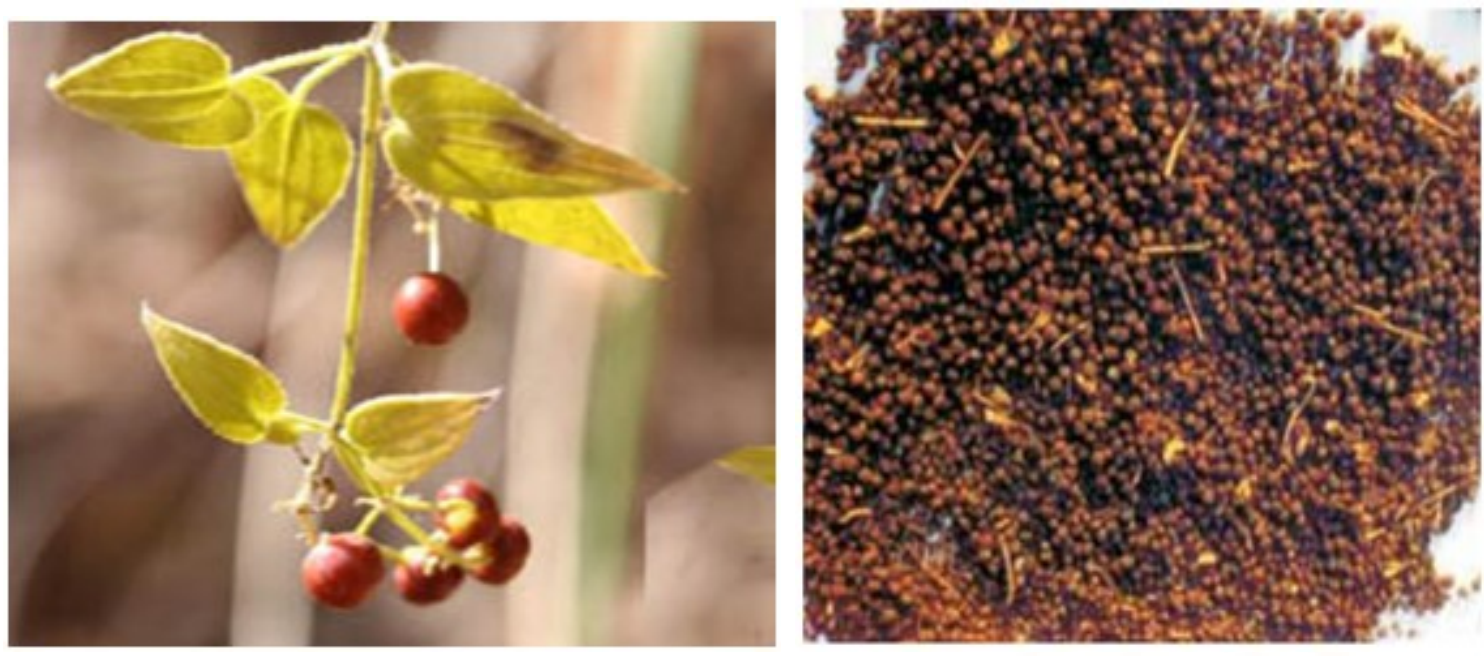

(C) Mature Fruit Stage

(D) Seeds of Rubia cordifolia

\section{HISTORY AND DISTRIBUTION:}

It is distributed throughout the lower hills of Indian Himalayas in the North and Western Ghats in the South, and Japan, Indonesia, Ceylon, Malay, Peninsula, Java and Tropical Africa in moist temperature and tropical forest, upto an altitude of $3500 \mathrm{~m}^{21,22}$

III. BOTANICAL DESCRIPTION:Rubia cordifolia roots are Very long, cylindric, flexuose with a thin red bark, Stems are often many yards long, rough, grooved, becoming slightly woody at the base. Rubia cordifolia barks are White, branches scan dent by means of numerous divaricate or deflexed branches lets and petioles, quadrangular, sometimes prickly on the angles, glabrous, shining. This plant Leaves are 3.8-9 by $1.6-3.5 \mathrm{~cm}$, in wholes of 4(one pair of each whorl often larger and with longer petioles than the other) ovate, acute, the lower leaves larger than the up-per, all scabrous above, on the nerves beneath, and on the margins with minute white prickles, base rounded or slightly cordate, the base of the upper leaves sometimes acute, all 5 nerved from the base, petioles triangular with many sharp recurved prickles on the edges, often deflexed. stipules 0 . Flowers are In terminal panicled cymes, branches trichotomous, spreading, bracts ovate, acute, leafy. Calyx $-0.85 \mathrm{~mm}$ long, tube globose, glabrous limb 0 and Corolla Greenish, divided nearly to the base, tube scarcely any, lobes 5 , ovate, acute, $3 \mathrm{~mm}$ long, style 2, stigma globose. These plants Fruitts are 4-6 mm diameter, didymous or globose, smooth, shining, purplish black when ripe, dried and pieces of pericarp and other refuse separated by sifting. It occurs mostly in loamy soil rich in humus. the rainfall is high in the regions in which this plant grows. The plant is a climber and requires support for growth. The plant is propagated through seeds and two node root cuttings. The seeds are collected during December and January. It is preferable to use seeds for large scale cultivation, considering the cost factor and high rate of germination. ${ }^{23-25}$

\section{PHYTOCHEMICAL STUDIES:}

Rubia cordifolia (Manjistha) basically known for its anthraquinones

phytochemical and naphthohydroquinones constituents $^{26}$. The major phytoconstituents of Rubia cordifolia reported include Rubiadin ${ }^{27}$ Rubicordone $\mathrm{A}^{28}$, Rubiasins $\mathrm{AC}^{29}$, Rubiatriol (triterpenoid), 6-methoxygeniposidic acid an iridoid glycoside ${ }^{30}$ and two pentacyclic triterpenoid- Rubicoumaric acid and Rubifolic $\operatorname{acid}^{31,32}$. Mollugin, furomollugin, dehydro-alphalapchone are isolated from chloroform fraction ${ }^{33}$. The primary chromophores present in Rubia cordifolia are alizarin, purpurin, pseudopurpurin xanthopurpurin, munjistin, rubiadin. All of the chromophores share the base 9,10 anthraquinone structure but with different functional groups at carbons 1-4 (Figure B) ${ }^{34}$.

\begin{tabular}{|l|l|}
\hline Alizarin & $\mathrm{R} 1=\mathrm{R} 2=\mathrm{OH}, \mathrm{R} 3=\mathrm{R} 4=\mathrm{H}$ \\
\hline Purpurin & $\mathrm{R} 1=\mathrm{R} 2=\mathrm{R} 4=\mathrm{OH}, \mathrm{R} 3=\mathrm{H}$ \\
\hline Pseudopurpurin & $\mathrm{R} 1=\mathrm{R} 2=\mathrm{R} 4=\mathrm{OH}, \mathrm{R} 3=\mathrm{COOH}$ \\
\hline Xanthopurpurin & $\mathrm{R} 1=\mathrm{R} 3=\mathrm{OH}, \mathrm{R} 2=\mathrm{R} 4=\mathrm{H}$ \\
\hline Munjistin & $\begin{array}{l}\text { R1= R3=OH, R2=COOH, } \\
\text { R4=H }\end{array}$ \\
\hline Rubiadin & $\mathrm{R} 1=\mathrm{R} 3=\mathrm{OH}, \mathrm{R} 2=\mathrm{CH} 3, \mathrm{R} 4=\mathrm{H}$ \\
\hline
\end{tabular}

Table 2: Structure of primary chromophores found in Indian Madder. 
Four naphthoic acid esters namely rubilactone, 3'carbomethoxy-4'-hydroxy-naphtho[1',2'-2,3]furan, dihydromollugin and 3-carbomethoxy-2(3'hydroxy)isopentyl-1,4-naphthohydroquinone-1-

Obeta- D-glucoside were isolated from the roots of Rubia cordifolia ${ }^{35}$. Identification of aroma compounds in Rubiae Radix (dried roots of Rubia cordifolia) done by gas chromatography. As a result of 43 components, accounting for $91.5 \%$ of total oil detected, in which mollugin (19.6\%), furomollugin $(17.4 \%)$, eugenol $(12.7 \%)$, (E)-anethole $(10.6 \%)$, 4tert-butyl-2-phenyl phenol (9.9\%), menthol (2.7\%) are the main components ${ }^{36}$.

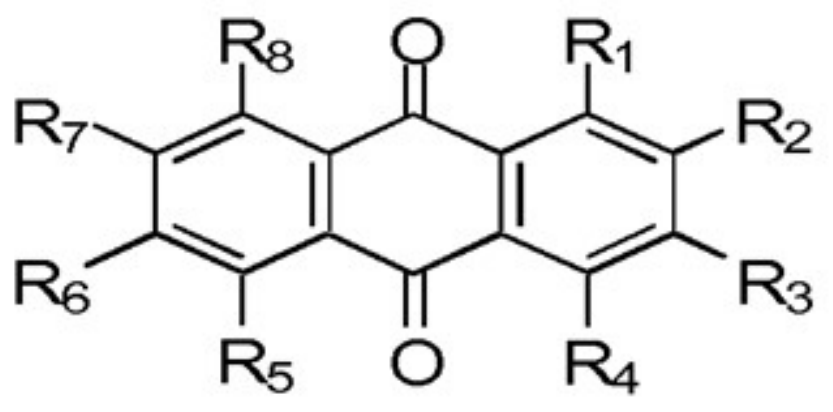

Figure 2: Rubia cordifolia Phytochemical Structure

Different classes of bioactive compounds such as anthraquinones and their glycosides, naphthoquinones and glycosides, terpenes, bicyclic hexapeptides, iridoids, ${ }^{37}$ carboxylic acids (malic, citric, quinic, rosmarinic acids) and saccharides (xylose, ribose, fructose, glucose, sucrose, primverose) were isolated from various parts of $R$. cordifolia. The roots contain a mixture of purpurin, munjistin, small amounts of xanthopurpurin and pseudopurpurin. Alizarin (1, 3dihydroxy-2-ethoxymethyl- 9, 10-anthraquinone), mollugin (1-hydroxy-2-methyl-9, 10-anthraquinone), 1, 3, 6-trihydroxy-2-methyl-9, 10- anthra-quinone-3O-(6'-Oacetyl)- $\alpha$-L-rhamnosyl $(1 \rightarrow 2)-\beta$ - D-glucoside, 1, 3, 6-tri hydroxy-2-methyl-9, 10- anthraqueinone-3O- $\beta$-L-rhamnosyl $(1 \rightarrow 2)-\beta$-D-glucoside, $1, \quad 3$, 6trihydrozy-2-methyl-9, 10-anthraquinone-3-O-(6'- Oacetyl)- $\beta$-D-glucoside, 2 -carbomethyoxy+++-3prenyl-1, 4-naphthohydroquinone di- $\beta$-D-glucoside, rubimallin, $\beta$ - sitosterol and daucosterol were also isolated from roots. ${ }^{38}$ Several naphthoquinones and hydroxyl anhraquinones and their glycosides were also isolated. ${ }^{39}$ 1-hydroxy 2-methyl anthraquinone, nordamnacanthal, physcion and 1, 4 dihydroxy 6methyl-anthraquinone, ${ }^{40}$ rubiatriol, ${ }^{41}$ 1-hydroxy 2methoxy anthraquinone; 1, 4- dihydroxy 2- methyl 5methoxy anthraquinone; 1, 3- dimethoxy 2-carboxy anthraquinone, rubiadin, ${ }^{42}$ naphthaquinones, ${ }^{43} 1$, 4- dihydroxy 2- methylanthraquinone and 1, 5-dihydroxy 2- methylanthraquinone and 3-prenyl methoxy 1, 4naphthoquinone ${ }^{44}$.

\section{PHARMACOLOGICAL STUDIES:}

\section{A. Anti Diabetic Property:}

Effect of alcoholic extract of roots of Rubia cordifolia was studied on elevated blood glucose level in alloxan treated animals. The extract reduced the blood sugar level raised by alloxan. Alcoholic extract enhanced brain $\gamma$-amino-n-butyric acid (GABA) levels and decreased brain dopamine and plasma corticosterone levels. Acidity and ulcers caused due to cold restraint stress were inhibited by alcoholic extract. Animals treated with alcoholic extract spent more time in open arm in elevated plus maze model. It also antagonized scopolamine induced learning and memory impairment. Baclofen induced catatonia was potentiated by alcoholic extract. 45 The hypoglycaemic activity of the alcoholic extract of roots of Rubia cordifolia (RCAE, 50,100 and 200 $\mathrm{mg} / \mathrm{kg}$, p.o.) was studied in normal, glucose fed and alloxan induced diabetic rats.

The normal rats were treated with single dose of $\operatorname{RCAE}(200 \mathrm{mg} / \mathrm{kg}$, p.o.) reduced the blood glucose by $20.4 \%$. The rats pre treated with RCAE (200 $\mathrm{mg} / \mathrm{kg}$, p.o.) improved oralglucose tolerance by 124.7 $\%$ at $1 / 2 \mathrm{~h}$ compared to glucose fed rats, exogenously injected insulin (1 IU/kg, s.c.) with RCAE (200 $\mathrm{mg} / \mathrm{kg}$, p.o.) caused $26 \%$ potentiation of hypoglycaemic effect at $6 \mathrm{~h}$ as compared with alone insulin treatment. ${ }^{46}$ The study was designed to investigate the effect of alcohol extract of leaves of Rubia cordifolia Linn.in normal and alloxan induced diabetic rats. Rubia cordifolia alcohol extract was evaluated for its acute toxicity in female mice. Two doses of Rubia cordifolia alcohol extract were selected and were evaluated for antidiabetic activity in alloxan induced diabetic male rats and for hypoglycemic activity in normal fasted rats. In normal treated rats both the doses of Rubia cordifolia alcohol extract, 200 and $400 \mathrm{mg} / \mathrm{kg}$ decrease (d) the blood glucose level by 32.15 and $39.02 \%$, respectively compared to glibenclamide $(600 \mu \mathrm{g} / \mathrm{kg})$ by $45.72 \%$ after 15 days of treatment. In addition, the extract also showed a favorable effect on glucose disposition in glucose fed hyperglycemic rats after $90 \mathrm{~min}$ of glucose administration. In alloxan induced diabetic rats both the doses of Rubia cordifolia alcohol extract decreases the blood glucose level by 48.46 and 
$51.56 \%$, respectively compared to the glibenclamide by $57.28 \%$ after 15 days treatment ${ }^{47}$.

\section{B. Anti Inflammatory Effect:}

Rubia cordifolia, Linn. (Indian Manjishtha), was studied for the antiinflammatory effect in rats with carrageenan paw oedema. The plant showed significant anti inflammatory activity at a dose of 10 and $20 \mathrm{ml} / \mathrm{kg}$ of the water extracts. The activity was comparable to that of phenylbutazone $(100 \mathrm{mg} / \mathrm{kg})$. The in vivo antioxidant activity of alcoholic extract of the roots of Rubia cordifolia Linn. (RC) and to study its influence on ethanol induced impairment of immune responses. Chronic administration of ethanol decreased the humoral and cell mediated immune response, phagocytosis, phagocytosis index, TLC, GSH, CAT and SOD activities and increased the LPO. These influences of ethanol were prevented by concurrent daily administration of $\mathrm{RC}$ and the effect was comparable with that of the combination of vitamin $\mathrm{E}$ and $\mathrm{C} .{ }^{48}$

Anti inflammatory and anticancer compounds from three medicinal plants, viz. Ventilago madraspatana Gaertn. Rubia cordifolia Linn. and Lantana camara Linn were investigated. The NO* scavenging potential of selected plant extracts was determined on LPS/IFN gamma activated murine peritoneal macrophage cultures, and iNOS and COX-2 expression was evaluated by Western blot analysis. Bio assay guided fractionation yielded four compounds: physcion and emodin from : V. madraspatana, 1-hydroxytectoquinone from $R$. cordifolia. The anti inflammatory activity of these compounds was tested through the carrageenan induced rat paw oedema model. They were then tested against a murine tumour (Ehrlich ascites carcinoma), and three human cancer cell lines, namely A375 (malignant skin melanoma), Hep2 (epidermoid laryngeal carcinoma) and U937 (lymphoma). All four compounds dose dependently inhibited NO through suppression of iNOS protein without affecting macrophage viability. Physcion and emodin caused $65-68 \%$ reduction of oedema volume at $40 \mathrm{mg} / \mathrm{kg}$, which validated there in vivo anti inflammatory effect. 1-Hydroxytectoquinone and oleanonic acid exhibited promising cytotoxicity against A375 cells. ${ }^{49}$

\section{Hepatoprotective Activity:}

The hepatoprotective activity of an aqueous methanol extract of Rubia cordifolia (Rubiaceae) was investigated against acetaminophen and CCl4induced hepatic damage. Acetaminophen produced 100\% mortality at a dose of $1 \mathrm{~g} / \mathrm{kg}$ in mice while pretreatment of animals with plant extract $(500$ $\mathrm{mg} / \mathrm{kg}$ ) reduced the death rate to $30 \%$. Acetaminophen at a dose of $640 \mathrm{mg} / \mathrm{kg}$ produced liver damage in rats as manifested by the rise in serum levels of GOT and GPT to $1447 \pm 182$ and $899 \pm 201$ IU/L $(n=10)$ respectively, compared with respective control values of $97 \pm 10$ and $36 \pm 11$. Pretreatment of rats with plant extract $(500 \mathrm{mg} / \mathrm{kg})$ lowered significantly $(p<0.005)$ the respective serum GOT and GPT levels to $161 \pm 48$ and $73 \pm 29 .^{50}$

\section{Anti microbial activity:}

The root extract of Rubia cordifolia was found to have antimicrobial activity against various pathogenic bacteria. Sitosterol and daucosterol possessed antibacterial activity. The root extracts constituents such as anthraquinones and flavonoids were found to suppress the activity of phytopathogens of Gossypium. Aldehyde aceate, dihydromollugin and rubimallin were reported to have significant antibacterial activity against Klebsiellap neumonia. Ethanolic extract of Rubia cardifolia was found to inhibit $\beta$-Lactamase producing uro-patho-genic E. coli. $^{51}$ The chloroform and the methanolic extracts of Rubia cardifolia reported to have antibacterial activity on gram-positive strains and gram negative Pseudomonas aeruginosa in a dose dependent manner. The aqueous extract of Rubia cordifolia was found to active against Bacillus subtilis and Staphylococcus aureus. Rubia cordone was reported to have considerable antimicrobial activity against Gram positive bacteria like Bacillus subtilis, Streptococcus faecalis and Bacillus cereus. The green synthesized silver nano particles using Rubia cordifolia plant root extract were reported to have highly inhibitory activity of the bacterial pathogens like Vibrio alginolyticus, Pseudomonas aeroginosa, Shigellaspp, Plesiomonss higelloides and Vibrio parahae molyticus. $^{52}$

\section{E. Immunomodulating activity:}

The alkaloids, cardiac glycosides, tannins, flavonoids and phenols in Rubia cordifolia are responsible for enhanced immunemodulation. The ethanolic extract of the whole plant found to exhibit immunosuppressive activity, cell mediated and humoralimmunopotentiating activity. ${ }^{53}$ The extracts of Rubiacordifolia and Rubiadianthus were found to inhibit the IgE production in peanut allergic mice. In another study revealed that, the administration of 
ethanolic plant extract to cyclophosphamide exposed animal was found to enhance immune responses. ${ }^{54}$

\section{F. Anti oxidant activity}

Rubia cordifolia contains a wide variety of antioxidants like alizarin, hydroxyl anthraquinones 55 and rubiadin ${ }^{56}$ which have been using in various medicaments. Hydroxy groups on one benzene ring of the anthraquinone structure were essential for hydroxyl anthraquinones to show the activity; its orthodihydroxy structure could greatly enhance their effect, and glycosylation reduced activity. ${ }^{57}$ The study of in vivo antioxidant activity and its influence on ethanol induced immunosupression showed that the concurrent daily administration of madder prevented the decrease of humoral and cell mediated immune response, phagocytosis index, leukocyte count, glutathione content, catalase and superoxide dismutase activities etc., which were comparable with that of the combination of vitamin $\mathrm{E}$ and $\mathrm{C}^{58}$ Rubiadin prevented lipid peroxidation induced by FeSO4 and butyl hydroperoxide in a dose dependent manner. ${ }^{59,60}$ Hexane and ethyl acetate fraction of root showed maximum free radical scavenging activity due to anthraquinones and their glycosides present in it. $R$. cordifolia extracts can protect peroxidation and reduced glutathione content in rat liver homogenate compared with vitamin $\mathrm{E}$ and parabenzoquinone. ${ }^{61}$ The alcoholic root extract has some effect on body weight due to rubiadin.

\section{G. Anti tumour activity:}

The cyclic hexapeptides and quinones of Rubia exhibited a significant anticancer activity against various proliferating cells. The hexapeptides showed potent antitumour activity by binding to eukaryotic $80 \mathrm{~S}$ ribosomes resulting in inhibition of aminoacyl tRNA binding and peptidyl - tRNA translocation, thus leading to the stoppage of protein synthesis 62 . The antitumor activity of RA-700, a cyclic hexapeptide isolated from R. cordifolia, was evaluated in comparison with deoxybouvardin and vincristine (VCR). The antitumor activity of RA-700 was similar to that of deoxybouvardin and VCR against P388 leukemia. As with deoxybouvardin and VCR, the therapeutic efficacy of RA-700 depends on the time schedule. RA-700 showed marginal activity against L1210 leukemia (50\% ILS), similar to that of deoxybouvardin but inferior to that of VCR. RA-700 inhibited Lewis tumor growth in the early stage after tumor implantation, whereas deoxybouvardin and VCR did not. A slight reduction of peripheral WBC counts was observed with the drug, but no reduction of RBC and platelet counts. Bilirubin, creatinine, GPT and GOT levels in plasma did not change with the administration of the drug ${ }^{63}$. The anticancer as well as antiviral property had been reviewed ${ }^{64}$. From the chloroform fraction of $\mathrm{R}$. cordifolia roots three constituents were isolated namely mollugin, furomollugin and dehydroalapchone. Mollugin has shown inhibition of passive cutaneous anaphylaxis (PCA) and protection of mast cell degranulation in rats.

It also exhibited considerable activity against lymphoid leukemia (P338) in mice ${ }^{65}$. The $\mathrm{R}$. cordifolia extract had shown a mitodepressive effect on the rate of cell division in bone marrow cells of Swiss male mice. This exposure time dependent reduction was attributed to the effect of inhibiting protein synthesis, suggesting probable effect of Rubia extract on the biosynthesis of certain amino acids as well as RNA synthesis ${ }^{66}$. R. cordifolia had shown an increase in leukocyte count in leucopenia ${ }^{67}$. The cytotoxic action of R. cordifolia had been evaluated with DNA Topoisomerases I and II inhibition and cytotoxicity of constituents isolated from the roots was tested. Topoisomerases I and II inhibitory activities were measured by assessing the relaxation of supercoiled pBR 322 plasmid DNA. The tetrazolium based colorimetric assay (MTT assay) was used for the cytotoxicity towards human colon carcinoma (HT-29), human breast carcinoma (MCF7) and human liver carcinoma (HepG2) cell lines. Seven compounds were isolated possessing cytotoxic activity ${ }^{68}$. Antitumor activity of RC-18, a pure isolate from R. cordifolia, was repeatedly tested in different sets of experiments on a spectrum of experimental murine tumors, viz P388, L1210, L5178Y, B16 melanoma, Lewis lung carcinoma and sarcoma-180. RC-18 exhibited significant increase in life span of ascites leukemia P388, L1210, L5178Y and a solid tumor B16 melanoma. However, it failed to show any inhibitory effect on solid tumors, Lewis lung carcinoma and sarcoma 180. Promising results against a spectrum of experimental tumors suggested that RC18 may lead to the development of a potential anti cancer agent ${ }^{69}$. The anticancer activity of extracts of R. cordifolia, tested against the P388 tumor system in BDF1 mice, compared well with that of the positive control, 5 fluorouracil ${ }^{70}$. 


\section{CONCLUSION:}

The above collected information regarding the uses and pharmacological activities of Rubia cordifolia is immensely useful for further studies. In the present scenario, ethnobotanical and traditional uses of natural compounds, especially of plant origin have received much attention, as they are well tested for their efficacy and are generally believed to be safe for human use. It is best classical approach in the search of new molecules for management of various diseases. Thorough screening of literature available on Rubia cordifolia depicted the fact that it is a popular remedy among the various ethnic groups, AYSUH and traditional practitioners for treatment of various ailments. Researchers are exploring the therapeutic potential of this plant as it has more therapeutic properties which have not been investigated. This review will be helpful in the development of polyherbal formulation as well as for conducting further research to explore the therapeutic potential of Rubia cordifolia.

\section{Financial Support and sponsorship} Nil

\section{Conflicts of interest}

None declared.

\section{REFERENCES}

1) Biswas TK, Maity LN, Mukherjee B. 2004. Wound healing potential of Pterocarpus santalinus Linn: a pharmacological evaluation. International Journal of Low Extreme Wounds 3: 143-150.

2) Mukherjee PK, Mukherjee K, Pal M, Saha BP. 2000. Wound healing potential of Nelumbo nucifera (Nymphaceae) rhizome extract. Phytomedicine 7: 66-73.

3) Babu M, Gnanamani A, Radhakrishan N, Priya K. 2002. Healing potential of Datura alba on burn wounds in albino rats. J Ethnopharmacology 83: 193- 199.

4) Purna SK, Babu M. 2000.Collagen based dressings/a review. Burns 26: 54-62.

5) Rao GM, Rao CV, Pushpagandan P. 2006. Hepatoprotective effects of rubiadin, a major constituent of Rubia cordifolia Linn. J Ethnopharmacology 103: 484- 490.
6) More BH, Gadgoli C, Padesi G. 2007. Hepatoprotective activity of Rubia Cordifolia. Pharmacologyonline 3: 73-79.

7) Wealth of India 2002. First supplementary Series, Vol-3, (D-I), Raw materials. Niscom. 130.

8) Singh R, Chauhan SM, Geetanjali. 2005. Anthraquinones and other biologically active compounds from the genus Rubia. J Chemistry and Biodiversity 1: 1241-1264.

9) Adwankar M. K., Chitnis M. P., Chemotherapy 28 (1982) 291

10) Antarkar SS, Chinwalla T, Bhatt N. 1983. Antiinflammatory activity of Rubia cordifolia Linn. In rats. Indian J Pharmacology 15 (3): 185-188.

11) Itokawa $H$,Takeya $K$,Mori $N$,et al.Studies on antitumor cyclic hexapeptides RA obtained from Rubia Radix,Rubiaceae on derivatives of RA-V and their in vivo activities.Chemical \& Pharmaceutical Bulletin,1984,32:3216-3226.

12) Singh R,Jain A,Panwar S,et al.Antimicrobial activity of some natural dyes.Dyes and Pigments,2005,66:99-102.

13) Rao ntt MGM,Rao CV,Pushpangadan P,et al.Hepatoprotective effects of rubiadin, a major constituent of Rubia cordifolia Linn.Journal of Ethnopharmacology, 2006,103:484-490.

14) Tripathi YB,Singh AV.Role of Rubia cordifolia Linn.in radiation protection.Indian Journal of Experimental Biology,2007,45(7):620-625.

15) Son JK,Jung SJ,Jung JH,et al.Anticancer constituents from the roots of Rubia cordifolia L.Chemical and Pharmaceutical Bulletin,2008,56(2):213-216.

16) Joharapurkar AA, Zambad SP, Wanjari MM, Umathe SN. 2003. In vivo evaluation of antioxidant activity of alcoholic extract of Rubia cordifolia Linn. and its influence on ethanolinduced immunosuppression Indian $\mathrm{J}$ Pharmacology 35: 232-236.

17) Antarkar DS,Chinwalla T,Bhatt N.Antiinflammatory activity of Rubia cordifolia Linn.in rats.Indian Journal of Pharmacology,1983,15:185188.

18) Tripathi YB, Sharma M. 1998. Comparison of antioxidant action of the alcoholic extract of R.cordifolia with Rubiadin. Indian J Biochemistry and Biophysics 12: 313. 
19) Warrier PK, Nambiar VPK, Ganapathy PM, Some Important Medicinal Plants of the Western Ghats India: A Profile, International Dev Res Cent, New Delhi, 2001, 329-342.

20) Gamble JS, Flora of the Presidency of Madras, Vol II, Adlard Sons, London, 1935.1-8.

21) Kirtikar KR, Basu BD. (1980) Indian Medicinal Plants. Vol II. 2nd edition. International Book Distributors, Dehradun, p. 1305-1307.

22) Khare CP. (2004) Encyclopedia of Indian medicinal plants, Rational Western Therapy \& Other Traditional Usage, Botany. Springerverlag Berlin Meidelberg, p. 406-407.

23) Kirthikar KR, Basu BD, ICS - Indian Medicinal Plants, 2nd ed. Vol.I, International Book Distributors, Dehradun; 1987. P - 1303-1305, Pp838.

24) Anonymous - The Wealth of India, A Dictionary of Indian Raw Materials \& Industrial Products, Raw Materials Vol.6,Sp-L-M, National Institute Of Science Communica-tion, Council of Scientific and Industrial Research, New Delhi; 1998. P -82, Pp- 483.

25) Kirthikar KR, Basu BD, ICS - Indian Medicinal Plants, 2nd ed. Vol.I, International eBook Distributors, Dehradun; 1987. P - 1303-1305, Pp838.

26) Itokawa H, Qiao Y, Takeya K. Anthraquinones and naphthohydroquinone from Rubia cordifolia. Phytochemistry. 1989; 28(12): 3465-3468.

27) Rao GMM, Rao CV, Pushpangadan P, Shirwaikar A. Hepatoprotective effects of rubiadin, a major constituent of Rubia cordifolia Linn. Journal of Ethnopharmacology. 2006; 103(3): 484-490.

28) Li X, Liu Z, Chen Y, Wang LJ, Zheng YN, Sun GZ and Ruan CC. Rubiacordone A: A new anthraquinones glycoside from the roots of Rubia cordifolia. Molecules. 2009; 14: 566-572.

29) Chang LC, Chavez D, Gills JJ, Fong HHS, Pezzuto JM, Kinghorn AD. Rubiasins A-C, new anthracene derivatives from the roots and stems of Rubia cordifolia. Tetrahedron Lett. 2000; 41(37): 7157- 7162 .

30) Arisawa $M$, Ueno $H$, Nimura $M$, Hayashi $T$, Morita N. Rubiatriol, a new triterpenoid from the Chinese drug "Qian Cao Gen," Rubia cordifolia.
Journal of Natural Products. 1986; 49(6): 11141116.

31) Wu LJ, Wang SX, Hua HM, Li $X$, Zhu TR, Miyase T, Ueno A. 6-methoxygeniposidic acid, an iridoid glycoside from Rubia cordifolia. Phytochemistry. 1991; 30(5): 1710-1711.

32) Talapatra SK, Sarkar AC, Talapatra B. Two pentacyclic triterpenes from Rubia cordifolia. Phytochemistry. 1981; 20(8): 1923-1927.

33) Gupta PP, Srimal RC, Verma N, Tandon JS. Biological activity of rubia cordifolia and isolation of an active principle. Pharmaceutical Biology. 1999; 37(1): 46-49.

34) Thomas J, Townsend JH, Hackney S, Strlic M. A chemiluminescence study of madder lakes on paper. Polymer Degradation and Stability. 2010; 95: 2343-2349.

35) Hua HM, Wang SX, Wu LJ, Li X, Zhu TR. Studies on naphthoic acid esters from the roots of rubia cordifolia L. Yao Xue Xue Bao. 1992; 27(4): 279- 282.

36) Miyazawa M, Kawata J. Identification of the key aroma compounds in dried roots of Rubia cordifolia. J Oleo Sci. 2006; 55(1): 37-39.

37) Singh R, Geetanjali, Chauhan SM, 9, 10Anthraquinones and other biologically active compounds from the genus Rubia, J. Chem. Biodivers., 1, 2004, 1241-1264.

38) Qiao YF, Wang SX, Wu LJ, Li X, Zhu TR, Studies on antibacterial constituents from the roots of Rubia cordifolia L., Yao Xue Xue Bao, 25, 1990, 834-839.

39) Wang SX, Hua HM, Wu LJ, Li X, Zhu TR, Studies on anthraquinones from the roots of Rubia cordifolia L., Yao Xue Xue Bao, 27, 1992, 743747.

40) Tessier AM, Delaveau P, Champion B, New anthraquinones in Rubia cordifolia roots, Planta Med., 41, 1981, 337-343.

41) Arisawa $M$, Ueno $H$, Nimura $M$, Hayashi $T$, Morita N, Rubiatriol, a new triterpenoid from the Chinese drug "Qian Cao Gen," Rubia cordifolia., J. Nat. Prod., 49, 1986, 1114-1116.

42) Dosseh C, Tessier AM, Delaveau P, Rubia cordifolia roots II New Quinones, Planta Med., 43, 1981a, 141-147. 
43) Koyama J, Ogura T, Tagahara T, Konoshima T, Kozuka J, Two naphthoquinones from Rubia cordifolia, Phytochem., 31, 1992, 2907-2908.

44) Dosseh C, Tessier AM, Delaveau P, New Quinones in Rubia cordifolia L. Roots III, Planta Med., 43, 1981b, 360-366.

45) Patil RA, Jagdale SC, Kasture SB: Antihyperglycemic, antistress and nootropic activity of roots of Rubia cordifolia Linn. Indian Journal of Experimental Biology 2006; 44:987992.

46) Somani SR, Jain SK, Singhai A K: Hypoglycaemic activity of roots of rubia cordifolia in normal and diabetic rats. Pharmacologyonline 1 2007; 162-169.

47) Viswanathaswamy AHM, Koti BC, Singh AK, Thippeswamy AHM: Anti-hyperglycemic and Anti-hyperlipidemic effect of Rubia cordifolia leaf extract on Alloxan-induced Diabetes. Journal of Pharmaceutical Sciences 2011;1(1):49-54.

48) Joharapurkar AA, Zambad SP, Wanjari MM and Umathe SN: In vivo evaluation of antioxidant activity of alcoholic extract of Rubia cordifolia linn. and its influence on ethanol-induced Immunosuppression. Indian Journal of Pharmacology 2003; 35:232-236.

49) Ghosh S, Das SM, Patra A, Hazra B: Antiinflammatory and anticancer compounds isolated from Ventilago madraspatana Gaertn., Rubia cordifolia Linn. and Lantana camara Linn. Journal of Pharmceutical Pharmacology 2010; 62(9):1158-66.

50) Gilani AH, Janbaz KH: Effect of Rubia cordifolia extract on acetaminophen and CCl4-induced hepatotoxicity. Phytotheraphy Research 1995; 9(5):372-375.

51) Basu S, Ghosh A, Hazra B, Evaluation of the antibacterial activity of VentilagomadraspatanaGaertn., Rubiacordifo-lia Linn. And Lantanacamara Linn.: isolation of Emodin and Physcion as active antibacterial agents, Phytother. Res., 2005; 19: 888-894.

52) Prajapati SN, Parmar KA, Anti-viral and in vitro free radi-cal scavenging activity of leaves of Rubiacordifolia, Int. J. Phytomed., 2011; 3: 98107.

53) Aslam M, Imtiyaz S, Tariq M, Chaudhary SS, Ahmed K, Unani immunomodulating Drugs: An overview, Int. J. Med. Pharm. Sci. Res. Review 2013; 1: 1-10.

54) Kasture VS, Deshmukh VK, Chopde CT, Anticonvulsant and behavioral actions of triterpene isolated from $\mathrm{Ru}$ biacordifoliaLinn.,Indian J. Exp. Biol., 2000; 38: 675-680.

55) Tripathi YB, Sharma M, Comparison of the antioxidant action of the alcoholic extract of Rubia cordifolia with rubiadin, Indian J. Biochem. Biophys., 3, 1998a, 313- 316.

56) Lodia S, Kansala L, Antioxidant activity of Rubia cordifolia against Lead toxicity, Int. J. Pharm. Sci. Res., 3, 2012, 2224-2232.

57) Cai Y, Sun M, Xing J, Corke H, Antioxidant phenolic constituents in roots of Rheum officinale and Rubia cordifolia: structureradical scavenging activity relationships.,J. Agric. Food Chem., 52, 2004, 7884-7890.

58) Joharapurkar AA, Zambad SP, Wanjari MM, Umathe SN, In vivo evaluation of antioxidant activity of alcoholic extract of Rubia cordifolia Linn. and its influenceon ethanolinduced immunosuppression, Indian J. Pharmacol., 35, 2003, 232-236.

59) Tripathi YB, Sharma M, Manickam M, Rubiadin, a new antioxidant from Rubia cordifolia, Indian J. Biochem. Biophys., 34, 1997, 302-306.

60) Pandey S, Sharma M, Chaturvedi P, Tripathi YB, Protective effect of Rubiacordifolia on lipid peroxide formation in isolated rat liver homogenate, Indian J.Exp. Biol., 32, 1994, 180183.

61) Tripathi YB, Shukla S, Sharma M, Shukla VK, Antioxidant property of Rubia cordifolia extract and its comparison with vitamin $\mathrm{E}$ and parabenzoquinone, Phytother. Res., 9, 1995b, 440-443.

62) Morita H, Yamamiya T, Takeya K, Itokawa $H$. (1992) New antitumour bicyclic hexapeptides, RA-XI, -XII, -XIII and -XIV from Rubia cordifolia. Chem. Pharm. Bull. 40, 1352-1354.

63) Kato T, Suzumura Y, Takamoto S, Ota K. (1987) Antitumor activity and toxicity in mice of RA700, a cyclic hexapeptide. Anticancer Res. 7, 329334. 
64) Rastogi RP, Dhawan BN. (1990) Anticancer and antiviral activities in Indian medicinal plants: A review. Drug Dev. Res. 19, 1-12.

65) Gupta PP, Srimal RC, Verma N, Tandon JS. (1999) Biological Activity of Rubia cordifolia and Isolation of an Active Principle. Pharm. Biol. 37, 46-49.

66) Abderrahman SM. (2004) Mitodepressive effect of Rubia cordifolia extract on the bone marrow cells of mice. Cytologia 69, 307-311.

67) Zhang ZH. (1983) Clinical observation on the increase of leukocyte count in leucopenia promoted by diethylester Rubia cordifolia L. Zhong Xi Yi Jie He Za Zhi 3, 98-99.
68) Son JK, Jung JH, Lee CS, Moon DC, Choi SW, Min BS, Woo MH. (2006) DNA Topoisomerases I and II Inhibition and Cytotoxicity of Constituents from the Roots of Rubia cordifolia. Chem. Inform. 38.

69) Adwankar MK, Chitnis MP. (1982) In vivo anticancer activity of RC-18: a plant isolate from $\mathrm{R}$. Cordifolia Linn. against a spectrum of experimental tumour models. Chemotherapy 28, 291-293.

70) Adwankar MK, Chitnis MP, Khandalekar DD, Bhadsavale CG. (1980) Anti-cancer activity of the extracts of Rubia cordifolia Linn. Indian J. Exp. Biol.

18 ,

102. 